Review

\title{
Acetylcholine and Its Receptors in Honeybees: Involvement in Development and Impairments by Neonicotinoids
}

\author{
Bernd Grünewald * and Paul Siefert \\ Institut für Bienenkunde, Polytechnische Gesellschaft, FB Biowissenschaften, Goethe-Universität Frankfurt am \\ Main, Karl-von-Frisch-Weg 2, D-61440 Oberursel, Germany; siefert@bio.uni-frankfurt.de \\ * Correspondence: b.gruenewald@bio.uni-frankfurt.de; Tel.: +49-6171-21278
}

Received: 2 October 2019; Accepted: 19 November 2019; Published: 22 November 2019

check for updates

\begin{abstract}
Acetylcholine (ACh) is the major excitatory neurotransmitter in the insect central nervous system (CNS). However, besides the neuronal expression of ACh receptors (AChR), the existence of non-neuronal $\mathrm{AChR}$ in honeybees is plausible. The cholinergic system is a popular target of insecticides because the pharmacology of insect nicotinic acetylcholine receptors (nAChRs) differs substantially from their vertebrate counterparts. Neonicotinoids are agonists of the nAChR and are largely used in crop protection. In contrast to their relatively high safety for humans and livestock, neonicotinoids pose a threat to pollinating insects such as bees. In addition to its effects on behavior, it becomes increasingly evident that neonicotinoids affect developmental processes in bees that appear to be independent of neuronal AChRs. Brood food (royal jelly, worker jelly, or drone jelly) produced in the hypopharyngeal glands of nurse bees contains millimolar concentrations of ACh, which is required for proper larval development. Neonicotinoids reduce the secreted ACh-content in brood food, reduce hypopharyngeal gland size, and lead to developmental impairments within the colony. We assume that potential hazards of neonicotinoids on pollinating bees occur neuronally causing behavioral impairments on adult individuals, and non-neuronally causing developmental disturbances as well as destroying gland functioning.
\end{abstract}

Keywords: insecticides; Apis mellifera; brood; larvae; nicotinic acetylcholine receptors; royal jelly

\section{Introduction}

Acetylcholine $(\mathrm{ACh})$ is an evolutionary highly-conserved signaling molecule. It preceded the appearance of the nervous system since it is expressed in bacteria, archaea, in eucaryotic unicellular organisms, and in higher organisms such as plants, fungi, and animals [1]. Therefore, the neuronal system basically utilizes the existing cholinergic system and improved the communication speed by releasing $\mathrm{ACh}$ from vesicles during synaptic transmission. However, the non-neuronal cholinergic system remains side-by-side to the neuronal cholinergic system within animals. The functional principles of both systems are basically similar. They comprise of choline acetyltransferase (ChAT) to synthesize ACh, receptors for ACh of the muscarinic (mAChR) and the nicotinic type (nAChR), ACh-degrading esterases (AChE) and choline transporters (ChT) for the uptake of choline after ACh degradation. In addition to its expression in the nervous system, these components have been widely localized in epithelial and endothelial tissues [2], in reproductive organs [3], and in muscle and immune cells. Thus, numerous cell functions can be regulated by ACh, such as gene expression, proliferation, differentiation, cytoskeletal organization, cell-cell contact, locomotion, migration, ciliary activity, electrical activity, secretion, and absorption [4].

Compared to vertebrates, the non-neuronal cholinergic system of insects is largely understudied, although it is crucial during all developmental stages, and ACh, AChE, and ChAT are present in very 
much higher titers than in nervous tissues [5]. In most insect species, two AChE are present, and a large group of insecticides specifically target those esterases, such as organophosphates and carbamates [6]. In Apis mellifera one of the AChEs is membrane-bound and found in the CNS (AmAChE2), while the other is soluble (AmAChE1) and additionally found in the thorax, abdomen, and leg in non-neuronal tissue and the peripheral nervous system [7]. Apparently, the amount of the soluble AmAChE1 is regulated by the breeding activity of honey bee colonies, which provides further evidence for the influence of the cholinergic system on reproduction in insects [8]. In Tribolium castanaeum, expression of the AChE gene TcAce2 is important during female reproduction, embryo development, and offspring growth [9]. In Drosophila melanogaster, which has only one AChE gene, a non-neuronal effect was reported in which $\mathrm{ACh}$, after its transport through the hemolymph, regulates the heart rate [10]. The importance of ACh for the insect immune responses is suggested since cholinergic disrupting chemicals impair immune responses [11,12]. Furthermore, initial evidence shows that hemocytes and the fatbody express nAChRs subunits in bees [13].

Cholinergic synaptic transmission has been intensively studied as it is prevalent within the insect brain. Nicotinic acetylcholine receptors have been localized in most brain neuropils, and functional $\mathrm{nAChRs}$ were characterized in vitro in various species (cf. [14] for review). Insect $\mathrm{nAChRs}$ are pentameric ionotropic receptors and cation channels with a high $\mathrm{Ca}^{2+}$ permeability (e.g., [15,16]). Their physiologies are in accordance with a function during excitatory synaptic transmission within the insect brain. Their molecular and functional similarities (e.g., high $\mathrm{Ca}^{2+}$-permeability and sequence homologies) to the vertebrate neuronal nAChRs imply that they also mediate modulatory functions. Accordingly, cholinergic signal transduction is required for olfactory learning and memory formation in insects (reviews: [17-19]). Honeybee nicotinic receptors share many features of insect nAChRs with respect to localization [20], pharmacology [21-23], permeability [15], and molecular identity [24-26]. The pharmacology differs substantially from its vertebrate counterparts [27,28]. Therefore, neonicotinoids have been developed that specifically target insect nAChR-dependent synaptic transmission, acting agonistically on the receptor with high specificity [29,30] (see also: [31]).

Neonicotinoids are a widely used group of insecticides. Not surprisingly, one of the problems with agricultural neonicotinoid applications is that they also bind to cholinergic receptors and induce currents through neuronal nAChRs [23,32-34] of pollinating insects, such as honeybees or bumblebees, and impair cholinergic transmission and-as a consequence-behavioral output. Socially living bees may be affected in several ways. Firstly, as adults, during foraging, during trophallactic contact, or by consumption of stored contaminated nectar, honey, or pollen. Secondly, as larvae after been fed with contaminated brood food. Therefore, bees need to be protected from exposure to neonicotinoids. Many studies investigated survival after insecticide treatment targeting the cholinergic system [35-42], and numerous studies have examined their effect on brood development by registering colony constitutions of honeybees (e.g., [43-45]) or bumblebees (e.g., [46-48]). Furthermore, sub-lethal neonicotinoid effects on adult honeybees comprise disturbances of navigation and orientation [49-51], walking behavior [52], learning and memory [53,54], foraging behavior [55], and nurse-larva-interactions [56]. For comprehensive overviews on sub-lethal neonicotinoid effects on honeybees, see [57-60]. Despite the fact that field studies largely failed to unambiguously demonstrate adverse effects of treated crop fields on whole hives the behavioral experiments clearly indicate impairments on individually treated honeybees. It is plausible to assume that the reported deficits also occur in those hives that appear vital upon superficial inspection.

The mode of action through which neonicotinoids induce these effects may be manifold. Certainly, acting via neuronal $\mathrm{nAChRs}$ is one of the major routes. In addition to this mechanism, neonicotinoids may affect muscarinic AChRs that are, as yet, largely uncharacterized in bees. A third way, which we assume to be particularly important for developmental effects, is via non-neuronal AChRs. Here, we review the properties of honeybee $\mathrm{nAChRs}$ and the actions of neonicotinoids on the neuronal receptors. We will then discuss the effects of neonicotinoids on larval and adult development and present an integrative model of cholinergic signaling and disturbances by neonicotinoids. 


\section{Acetylcholine Receptors in the Honeybee}

Acetylcholine is the major excitatory transmitter in the insect brain (reviews in [14]). Immunolabelling of the nAChR or ChAT, as well as the histochemistry of AChE activity and in situ hybridization studies of the various $\mathrm{nAChR} \alpha$-subunits identified several pathways and neuropils that are presumably cholinergic in insects. In bees, the olfactory system and the visual neuropils probably rely mainly on cholinergic signal transmission [20]. Axons of the olfactory receptor neurons probably release ACh onto postsynaptic neurons within the antennal lobes (ALs), and a subpopulation of projection neurons from the AL form cholinergic synapses with Kenyon cells within the mushroom body (MB) lip regions. Honeybee AL neurons, as well as Kenyon cells, stain against nAChR antibodies [20]. The lamina, medulla, and lobula of bees contain cholinergic neurons as well as neurons of the central complex.

The honeybee $\mathrm{nAChR}$ is an ionotropic receptor of the cys-loop receptor family, a pentameric receptor whose stoichiometry is as yet unknown [26]. Sequence analyses identified nine different $\alpha$-subunits, Amel $\alpha 1-9$, and two $\beta$-subunits, Amel $\beta 1-2[24,25,61]$. Amel $\alpha 5$, Amel $\alpha 7$, and Amel $\alpha 8$ are expressed in MB Kenyon cells and in AL neurons. Amel $\beta 2$ subunits are found in Kenyon cells. In the optic lobes, Amel $\alpha 2$, Amel $\alpha 3$, and Amel $\alpha 7-2$, expressions were identified [24,25]. The native honeybee nAChRs in Kenyon cells and AL neurons are cation-selective channels with a neuronal pharmacological profile. Pressure applications of ACh or nicotine induce rapidly activating inward currents in cultured bee neurons [15]. The nAChR of Kenyon cells has a high $\mathrm{Ca}^{2+}$-permeability [15,62], and calcium imaging experiments in vitro revealed a strong intracellular $\mathrm{Ca}^{2+}$ signal during the application of nicotinic agonists $[63,64]$. The $n A C h R$, therefore, mediates membrane depolarization and the direct influx of $\mathrm{Ca}^{2+}$ into the postsynaptic neuron upon activation. Currents through nAChR are blocked by nicotinergic blockers curare, methyllycaconitine, dihydroxy- $\beta$-erythroidine, hexamethonium, and mecamylamine [15,21-23]. ACh, as well as carbamylcholine, are full agonists, whereas nicotine, epibatidine, and cytisine are partial agonists [21]. Despite its neuronal profile, the honeybee nAChR has a rather unusual pharmacology as compared to its vertebrate counterparts. Since atropine blocks ACh-induced currents, a "mixed" pharmacology for the insect nAChR was suggested by some authors [28,65]. However, muscarinic agonists muscarine, pilocarpine, or oxotremorine do not induce currents through honeybee nAChRs [21]. Finally, the GABA ( $\gamma$-aminobutyric acid) receptor blockers picrotoxin, bicuculline, and fipronil, as well as the glycine receptor blocker strychnine, act antagonistically [21,22]. Neonicotinoids are agonists of the insect nAChRs (review: [66]). Due to their low human toxicity and their relative specificity to insect over vertebrate $\mathrm{nAChR}$, they represent a commercially very successful insecticide group $[67,68]$. Imidacloprid is a partial agonist of the honeybee nAChR (Kenyon cells: [23,33,34]; antennal lobe neurons: [22,32,62]), and clothianidin acts as a full agonist [34].

Behavioral pharmacological studies indicate that $\mathrm{nAChR}$ are involved during various phases of classical conditioning, memory formation, and retrieval (review: $[18,19])$. However, the effects caused by nicotinic antagonists are complex and often contradictory. Injections of the nAChR antagonists mecamylamine, $\alpha$-bungarotoxin (BGT), or methyllylcaconitine (MLA) into the honeybee brain impaired acquisition (mecamylamine, [69]) or long-term memory (BGT, MLA, [70]). Interestingly, odor information processing appears to be largely unaffected by pharmacological treatments since odor learning, per se, is not impaired while imidacloprid perfusions diminish odor signals in antennal lobe glomeruli [71]. That may indicate that the native $\mathrm{nAChR}$ within the bee brain in vivo differs from the $\mathrm{nAChR}$ investigated in vitro. At least several different receptors with differing pharmacologies (probably also different stoichiometries) are expressed in honeybees. Given that various blockers target different nAChR subtypes, it was assumed that at least two nAChR (one BGT-sensitive and one BGT-insensitive $\mathrm{nAChR}$ ) are differentially involved during olfactory learning and memory formation in bees (e.g., [70]; review: [18]). Therefore, care is needed by assigning the effects of various drugs or insecticides to certain nAChRs. Unfortunately, pharmacological experiments on the functions of nAChRs within the honeybee visual system are missing, although the optic lobes express nAChRs. 
Muscarinic acetylcholine receptors are $G$ protein-coupled receptors with seven transmembrane domains. In humans, five mAChRs (m1-m5) have been characterized that are expressed not only in the peripheral and central nervous system but also in epithelial (airway, skin, intestine, ovary, urothelium), endothelial (pulmonary vessels), immune, and mesenchymal (fibroblasts, tenocytes, smooth muscle fibres) cells [2]. The insect $m A C h R s$ are less well-studied. Two mAChRs were cloned and described in D. melanogaster, and T. castaneum (an A- and B-type), both activated by ACh but have different sensitivities to muscarine and binding of atropine and scopolamine. Both receptors have been identified in all arthropods with a sequenced genome [72]. Recently, a third (C-type) mAChR family has been described in D. melanogaster [73].

\section{Acetylcholine in Bee Development}

In several vertebrate tissues, ACh demonstrates a proliferative, trophic effect via nicotinergic and muscarinic receptors [3]. In insects, the cholinergic system is crucial during all developmental stages, and $\mathrm{ACh}, \mathrm{AChE}$, and $\mathrm{ChAT}$ are present in very much higher titers as compared to vertebrates [5]. Apart from its occurrence in honey and bee bread [74-78], bees apparently feed ACh to developing larvae, as it was found in millimolar concentrations in larval food [76]. This recent study confirms and extends earlier studies reporting surprisingly high ACh concentrations in brood food (see below).

Worker larval nutrition is categorized as "worker jelly" and "modified worker jelly", indicating a general shift in protein, sugar, and lipid contents [79] around day three of larval development [80]. This shift has also been reported for ACh content in worker nutrition. While larvae below $5 \mathrm{mg}$ weight receive a relatively high ACh amount in their food (1.1 mg free base per gram dry larval food [81]; erratum: 'Die Naturwissenschaften 47, p. 456, 1960') food for larvae weighing between 10 and $20 \mathrm{mg}$ contains less ACh $\left(0.73 \mathrm{mg} \mathrm{g}^{-1}\right)$. The oldest larvae received modified worker jelly with the least amount of ACh $\left(0.16 \mathrm{mg} \mathrm{g}^{-1}\right)$ [81]. This is generally consistent with the study by Wessler et al. (2016) reporting $4.13 \mathrm{mM}$ (estimated $0.72 \mathrm{mg} \mathrm{g}^{-1}$ ) ACh in worker jelly if the developmental state of 'larger larvae with visible food' [76] corresponds to 10 to $20 \mathrm{mg}$ weighting larvae. Drone food also contains relatively high ACh concentrations $\left(1.8,1.65\right.$, and $0.66 \mathrm{mg} \mathrm{g}^{-1}$ for drone larvae weighing $<5,10-30$, and $>30 \mathrm{mg}$, respectively) [81].

The reduction in the ACh content during worker development is conceivable since gland secretion decreases in favor of sugar containing food from the honey stomach [79], and ACh is synthesized in hypopharyngeal canal cells via membrane-bound ChAT [76]. The synthesis during jelly excretion and the surrounding acidity of $\mathrm{pH} 4.0$ makes ACh very stable in larval honey bee food [82] because AChE is not enzymatically active under such acidic conditions. ACh in brood food can even be preserved after two hours of boiling in water [74].

Royal jelly also contains high ACh amounts. It is fed to developing honey bee queens and, compared to worker nutrition, contains a higher amount of sugar [79]. According to [81], ACh content decreases from 1.7 to $1.1 \mathrm{mg} \mathrm{g}^{-1}$ in royal jelly in cells of young (weight $<5 \mathrm{mg}$ ) and old ( $>25 \mathrm{mg}$ ) larvae, respectively. This represents a $35 \%$ decrease during queen development compared to an $85 \%$ decrease during worker development and may influence caste determination. HPLC analyses quantified $8 \mathrm{mM}$ (1.4 $\left.\mathrm{mg} \mathrm{g}^{-1}\right) \mathrm{ACh}$ in freshly isolated royal jelly (2-3 h after the nursing of fertilized eggs) and $4.64 \mathrm{mM}$ (estimated $0.81 \mathrm{mg} \mathrm{g}^{-1}$ ) in commercially available royal jelly [76]. Experimentally reducing the ACh content in artificial brood food increased larval mortality [76]. ACh-uptake by larvae is, therefore, required for the proper development of queens, workers, and drones. It is produced from non-neuronal tissue and probably acts via non-neuronal AChRs.

\section{Neonicotinoids Affect Larval and Adult Development}

Although ACh is important during larval development, only a few studies exist that have investigated neonicotinoid effects on the bee ontogeny. However, most of the available studies investigating larval development describe a developmental delay and some abnormal appearances. Also, there is reason to assume that some effects occur in those adults that were exposed to neonicotinoids 
as larvae (e.g., [83,84]). Repeated administration of $0.2-20 \mathrm{mg} \mathrm{L}^{-1}$ thiamethoxam in artificial Apis mellifera rearing experiments caused more brownish larvae, delayed pupation time, and some larvae failed in eclosion during metamorphoses [35]. Delayed development was also reported when the larvae were fed $5 \mu \mathrm{g} \mathrm{kg}^{-1}$ [85] or $10 \mathrm{mg} \mathrm{L}^{-1}$ imidacloprid. Furthermore, honeybee larvae reared in combs with insecticide residues, including $45 \mathrm{\mu g} \mathrm{kg}^{-1}$ imidacloprid, showed retarded development [86]. While $30 \mathrm{or}$ $300 \mu \mathrm{g} \mathrm{kg}^{-1}$ imidacloprid fed to Osmia lignaria larvae delayed their development under field conditions, no effects were reported under laboratory conditions [87]. A recent study described a doubling of honeybee larval development time when fed $10 \mathrm{mg} \mathrm{L}^{-1}$ clothianidin and of total development time with $2 \mathrm{mg} \mathrm{L}^{-1}$ clothianidin in vitro. However, the pupal development time was not affected [40]. Video registrations of development within observation hives [56] showed that $200 \mu \mathrm{g} \mathrm{kg}^{-1}$ thiacloprid in sugar syrup fed to the colony prolonged the feeding timespan until capping of the cell by half a day. Similar effects were observed when colonies were fed $10 \mu \mathrm{g} \mathrm{kg}^{-1}$ clothianidin. Furthermore, high dosages of clothianidin (100 ppb) and thiacloprid $(8.8 \mathrm{ppm})$ prolonged the development times of eggs and from larval hatch to cell capping within the colonies. Interestingly, clothianidin increased pupal development time, whereas thiacloprid decreased it [56]. In the stingless bee Scaptotrigona aff. depilis thiamethoxam decreased development time in vitro from 15 to 10 days $(0.044 \mathrm{ng} / \mathrm{larva})$ or 8 days ( $4.375 \mathrm{ng} /$ larva) while pupal development increased from 12 to 18 and 17 days, respectively [39].

These in vitro insecticide experiments show that the cholinergic system is important for larval development and is disturbed by neonicotinoids. However, a direct delivery of neonicotinoids from nurse bees to larvae via brood food appears not to occur under field conditions. Virtually no pesticide residues were found in royal jelly, even when colonies were fed with high (75-800 $\mathrm{g} \mathrm{L}^{-1}$ active ingredient) pesticide concentrations. Only $0.016 \%$ of the consumed thiacloprid reaches the secreted royal jelly [88]. This is consistent with distributions of other insecticides within workers. Low radioactivity was measured in hypopharyngeal glands after individuals were fed with radiolabelled carbaryl and diflubenzuron [89] or carbofuran and dimethoate [90]. If direct transmission by honey was the main reason for residues in royal jelly, worker larvae would receive very little neonicotinoids since royal jelly seems to contain more sugar than worker jelly [79]. However, this may increase as the older worker larvae are fed modified royal jelly. As several studies demonstrate delayed larval development within honeybee colonies after chronic neonicotinoid treatment (e.g., [56,76,86]), impairments of important nursing morphologies within workers may cause such effects rather than direct feeding of toxic insecticides to larvae. As a consequence, cholinergic transmission could also be important for the development and maturation of adult bees.

The cholinergic system continues to develop in the adult honeybee. During the first week after adult eclosion, the brain activity of AChE increases and remains at this level until old age [91]. Due to the plasticity of each individual worker, the bee colony as a whole is very adaptive in its division of labor and can shift nursing and foraging activity due to environmental and colony demands. This adaptation is under the influence of various internal (e.g., colony size, brood size, diseases) and external factors (e.g., nutrition, pollen supply, season or weather, stressors like pesticides) and involves nutritional stimuli communicated via food exchange (cf. [92] for review). The subsequent development or degradation of the hypopharyngeal glands [93] is hormone-dependent. Newly emerged workers have undeveloped glands with small acini, and with nursing activity, they increase in size and produce the protein-rich jelly. The glands decrease in size and activity again when the worker starts to forage. As the nursing workers feed the young, other nest mates and the queen [94,95], glandular ACh could be consumed by all individuals of the colony throughout their whole life span. Therefore, a regulatory influence of ACh on adult development and behavior is plausible. If the exchanged food contains differing amounts of ACh, cholinergic social signaling is likely to contribute to gland development and function and would explain the disturbing effects of neonicotinoids and other xenobiotics described below.

When newly emerged bees in cages were fed with 2 and $3 \mu \mathrm{g} \mathrm{kg}^{-1}$ imidacloprid in sugar and pollen pastry, respectively, the acini of hypopharyngeal glands were 14.5 and 16.3 percent smaller in diameter than the control after 9 days and 14 days of exposure, respectively [96]. Similarly, after one 
week of $1 \mathrm{ppb}$ imidacloprid application in sugar syrup to colonies, 14-day old workers displayed reduced acini diameter sizes [97]. Similar effects were present when bees were exposed to 48 and $72 \mathrm{~h}$ treatment with $0.5 \mu \mathrm{g} \mathrm{kg}^{-1}$ imidacloprid in sugar solution [98] and in 10-day old bees after continuous feeding of 5 or $200 \mathrm{\mu g} \mathrm{kg}^{-1}$ imidacloprid under field and laboratory conditions [99]. Furthermore, caged honeybees chronically exposed to imidacloprid at $\mathrm{LC}_{50} / 5$ in sugar and pollen showed reduced acini diameter sizes after 6, 9, and 14 days [100]. Comparable results were published for 8 and 12 days of exposure to 10 and $40 \mu \mathrm{g} \mathrm{L}^{-1}$ thiamethoxam [101]. In addition to these morphological abnormalities, neonicotinoid exposure also impairs hypopharyngeal gland function because acetylcholine secretion into the brood food diminishes after clothianidin or thiacloprid feeding [76]. This probably leads to brood impairments in small hives under semi-field conditions. Expression of Amel $\alpha 3$ and Amel $\alpha 4$ $\mathrm{nAChR}$ subunits in the hypopharyngeal glands indicates an ACh-dependency of the glandular function, although ChAT activity is not acutely blocked by neonicotinoids, but requires chronic exposure [76]. Obviously, other xenobiotics that interfere with cholinergic signaling in honeybees may lead to similar disruptions in glandular function. Among them are the acaricide coumaphos, an organophosphate that inhibits the AChE, and other insecticides like the carbamate fenoxycarb (for review see: [102]). Effects on hypopharyngeal glands were also reported for the GABA receptor blocker fipronil, the herbicide glyphosate, or the fungicide pyraclostrobin [102].

\section{How Do Neonicotinoids Affect Honeybee Development?}

Several mechanisms may underlie the delays in development, including impairments of the endocrine system, altered gene expression of metabolic pathways, and an increased energy use due to detoxification mechanisms. Some studies suggest that neonicotinoids interfere with the honey bee endocrine system [103-105]. Juvenile hormone slows down larval development, as ligaturing the corpora allata results in shortened worker ontogenesis [106]. Therefore, neonicotinoids may increase juvenile hormone titers in bees. However, so far, it has only been demonstrated in Lepidopterans that imidacloprid increases juvenile hormone titers in larvae and adult females of Chilo suppressalis [107] and that the corpora allata is under a cholinergic regulation in Mythimna loreyi [108]. Several gene expression studies report an upregulation of detoxification enzymes, such as cytochrome p450s, and effects on protein translation involved in metabolic pathways after insecticide treatment [99,109-112]. Honeybees show 10-fold or greater shortfalls in detoxification enzymes compared to Drosophila melanogaster or Anopheles gambiae [113], which may cause unspecific health deficits due to low detoxification capacities. Moreover, some studies report a general reduction in protein amounts in workers after neonicotinoid treatment $[101,114,115]$ that promotes developmental delays. Imidacloprid and clothianidin were stated to alter protein, lipid, glucose, and glycogen levels and reduced bee body weight [105]. By contrast, newly emerged honeybees fed with nicotine up-regulate proteins involved in lipid, amino acid, glutathione, and nucleotide metabolism. The most up-regulated protein groups are related to energy metabolism and carbohydrate metabolism [116]. In larvae, proteins involved in energy and carbohydrate metabolism and developmental pathways were enriched after nicotine was fed in in vitro rearing experiments. Therefore, nicotine may promote larval growth [117]. These reports consistently show an influence of the cholinergic system on developmental processes within larvae and adult workers. The impairments of metabolic pathways could then result in morphological deficits in nurses and provoke reduced hypopharyngeal gland sizes that secrete less ACh into the queen, worker, and drone food.

\section{Conclusions and Outlook}

Neonicotinoid exposures affect honeybee vitality in various ways, behaviorally, morphologically, immunologically, and developmentally. These effects are mediated by neuronal and non-neuronal AChR. Figure 1 summarizes our current view concerning the developmental aspects of the cholinergic systems. We assume that ACh has a proliferative and/or trophic effect within honeybees and regulates gene expression, potentially via modulating juvenile hormone levels. Although evidence that juvenile 
hormone $(\mathrm{JH})$ titers are affected by cholinergic pathways is weak, it is likely, because JH plays a central role in honeybee developmental and maturing processes. The ACh-induced gene expression affects metabolic pathways that control larval development and adult hypopharyngeal gland size and function. This, in turn, regulates ACh secretion from the glands with the described effects on larval development. Therefore, neonicotinoid effects can translate into disturbed colony development due to impairments of cholinergic systems in the offspring, nurses, or both.

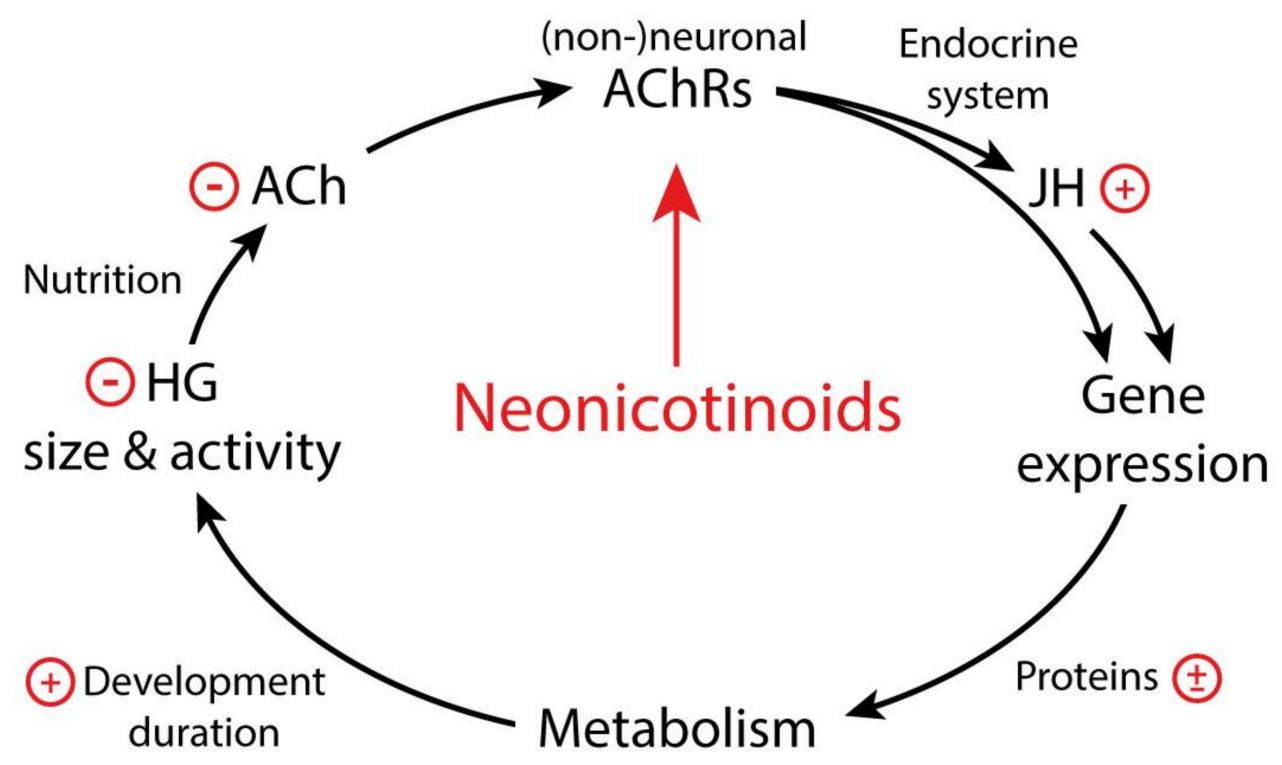

Figure 1. Metabolic and endocrine functions of acetylcholine (ACh) in honeybee adults and larvae and its disturbances by cholinergic pesticides, such as neonicotinoids. Impairments of neuronal or non-neuronal acetylcholine receptors (AChRs) of honeybees by neonicotinoids have been shown to increase (+) development duration of larvae and adults while reducing (-) hypopharyngeal gland (HG) size and its ACh secretion. This is likely to be a consequence of impaired energy and carbohydrate metabolism, preceded by up- or downregulation ( \pm ; via gene expression) of involved proteins, altering lipid, glucose, and glycogen metabolism. Therefore, ACh may directly or indirectly affect the endocrine system, as increased juvenile hormone $(\mathrm{JH})$ titers result in developmental delays (see text for further details).

We conclude that acetylcholine is a key signaling molecule in the individual bee, within the honeybee colony, and possibly in other social insect societies as well. As it acts on neuronal and presumably non-neuronal pathways and is socially transmitted between individuals, it is crucial for colony development and vitality. Interfering with this key molecule by insecticides causes multiple disturbances or unexpected side effects that may sum up to harmful threats even at low concentrations.

Obviously, several gaps exist in our knowledge of the mode of action of ACh signaling. While we know a lot about the neuronal AChR, hardly anything is published on the molecular identity or localization of the (various?) insect non-neuronal AChR. Such studies, however, are required to establish hypotheses on the interactions between $\mathrm{ACh}$ and the endocrine system, to understand the physiological mode of action of ACh during larval and adult development and, finally, to develop novel insecticides that are safer for beneficial insects.

Author Contributions: B.G. and P.S. equally contributed to this document.

Funding: This research was supported by the EU and Land Hessen, “Förderung von Maßnahmen zur Verbesserung der Erzeugung und Vermarktung von Honig in Hessen".

Conflicts of Interest: The authors declare no conflict of interest. 


\section{References}

1. Sastry, B.V.; Sadavongvivad, C. Cholinergic systems in non-nervous tissues. Pharmacol. Rev. 1978, 30, 65-132.

2. Wessler, I.; Kirkpatrick, C.J. Acetylcholine beyond neurons: the non-neuronal cholinergic system in humans. Br. J. Pharmacol. 2009, 154, 1558-1571. [CrossRef]

3. Wessler, I.K.; Kirkpatrick, C.J. Non-neuronal acetylcholine involved in reproduction in mammals and honeybees. J. Neurochem. 2017, 142, 144-150. [CrossRef] [PubMed]

4. Wessler, I.; Kilbinger, H.; Bittinger, F.; Kirkpatrick, C.J. The biological role of non-neuronal acetylcholine in plants and Humans. Jpn. J. Pharmacol. 2001, 85, 2-10. [CrossRef] [PubMed]

5. Smallman, B.N.; Mansingh, A. The cholinergic system in insect development. Annu. Rev. Entomol. 1969, 14, 387-408. [CrossRef] [PubMed]

6. Russell, R.J.; Claudianos, C.; Campbell, P.M.; Horne, I.; Sutherland, T.D.; Oakeshott, J.G. Two major classes of target site insensitivity mutations confer resistance to organophosphate and carbamate insecticides. Pestic. Biochem. Physiol. 2004, 79, 84-93. [CrossRef]

7. Kim, Y.H.; Cha, D.J.; Jung, J.W.; Kwon, H.W.; Lee, S.H. Molecular and kinetic properties of two acetylcholinesterases from the western honey bee, Apis mellifera. PLoS One 2012, 7, e48838. [CrossRef] [PubMed]

8. Kim, Y.H.; Kim, J.H.; Kim, K.; Lee, S.H. Expression of acetylcholinesterase 1 is associated with brood rearing status in the honey bee, Apis mellifera. Sci. Rep. 2017, 7, 1-8. [CrossRef]

9. Lu, Y.; Park, Y.; Gao, X.; Zhang, X.; Yao, J.; Pang, Y.-P.; Jiang, H.; Zhu, K.Y. Cholinergic and non-cholinergic functions of two acetylcholinesterase genes revealed by gene-silencing in Tribolium castaneum. Sci. Rep. 2012, 2, 288. [CrossRef]

10. Malloy, C.A.; Ritter, K.; Robinson, J.; English, C.; Cooper, R.L. Pharmacological identification of cholinergic receptor subtypes on Drosophila melanogaster larval heart. J. Comp. Physiol. B Biochem. Syst. Environ. Physiol. 2016, 186, 45-57. [CrossRef]

11. Brandt, A.; Gorenflo, A.; Siede, R.; Meixner, M.; Büchler, R. The neonicotinoids thiacloprid, imidacloprid, and clothianidin affect the immunocompetence of honey bees (Apis mellifera L.). J. Insect Physiol. 2016, 86, 40-47. [CrossRef] [PubMed]

12. Brandt, A.; Grikscheit, K.; Siede, R.; Grosse, R.; Meixner, M.D.; Büchler, R. Immunosuppression in honeybee queens by the neonicotinoids thiacloprid and clothianidin. Sci. Rep. 2017, 7, 4673. [CrossRef] [PubMed]

13. Pamminger, T.; Basley, K.; Goulson, D.; Hughes, W. First indication of acetylcholine-based communication in honeybee haemocytes and its modulation by a neonicotinoid insecticide. bioRxiv 2017, 105700. [CrossRef]

14. Thany, S.H. Advances in Experimental Medicine and Biology. In Insect Nicotinic Acetylcholine Receptors; Thany, S.H., Ed.; Springer: New York, NY, USA, 2010; Volume 683, ISBN 978-1-4419-6444-1.

15. Goldberg, F.; Grünewald, B.; Rosenboom, H.; Menzel, R. Nicotinic acetylcholine currents of cultured Kenyon cells from the mushroom bodies of the honey bee Apis mellifera. J. Physiol. 1999, 514, 759-768. [CrossRef] [PubMed]

16. Oertner, T.G.; Single, S.; Borst, A. Separation of voltage- and ligand-gated calcium influx in locust neurons by optical imaging. Neurosci. Lett. 1999, 274, 95-98. [CrossRef]

17. Grünewald, B. Cellular Mechanisms of Neuronal Plasticity in the Honeybee Brain. Handb. Behav. Neurosci. 2013, 22, 467-477.

18. Gauthier, M. State of the art on insect nicotinic acetylcholine receptor function in learning and memory. In Insect Nicotinic Acetylcholine Receptors; Thany, S.H., Ed.; Springer: New York, NY, USA, 2010; Volume 683, pp. 97-115.

19. Gauthier, M.; Grünewald, B. Neurotransmitter systems in the honeybee brain: functions in learning and memory. In Honeybee Neurobiology and Behavior; Galizia, C.G., Eisenhardt, D., Giurfa, M., Eds.; Springer: Dordrecht, Holland; Heidelberg, Germany; London, UK; New York, NY, USA, 2012; pp. 155-169.

20. Kreissl, S.; Bicker, G. Histochemistry of acetylcholinesterase and immunocytochemistry of an acetylcholine receptor-like antigen in the brain of the honeybee. J. Comp. Neurol. 1989, 286, 71-84. [CrossRef]

21. Wüstenberg, D.G.; Grünewald, B. Pharmacology of the neuronal nicotinic acetylcholine receptor of cultured Kenyon cells of the honeybee, Apis mellifera. J. Comp. Physiol. A 2004, 190, 807-821. [CrossRef] 
22. Barbara, G.S.; Zube, C.; Rybak, J.; Gauthier, M.; Grünewald, B. Acetylcholine, GABA and glutamate induce ionic currents in cultured antennal lobe neurons of the honeybee, Apis mellifera. J. Comp. Physiol. A 2005, 191, 823-836. [CrossRef]

23. Dupuis, J.P.; Gauthier, M.; Raymond-Delpech, V. Expression patterns of nicotinic subunits $\alpha 2, \alpha 7, \alpha 8$, and $\beta 1$ affect the kinetics and pharmacology of ACh-induced currents in adult bee olfactory neuropiles. J. Neurophysiol. 2011, 106, 1604-1613. [CrossRef]

24. Thany, S.H.; Lenaers, G.; Crozatier, M.; Armengaud, C.; Gauthier, M. Identification and localization of the nicotinic acetylcholine receptor alpha3 mRNA in the brain of the honeybee, Apis mellifera. Insect Mol. Biol. 2003, 12, 255-262. [CrossRef] [PubMed]

25. Thany, S.H.; Crozatier, M.; Raymond-Delpech, V.; Gauthier, M.; Lenaers, G. Apis $\alpha 2$, Apis $\alpha 7-1$ and Apis $\alpha 7-2$ : three new neuronal nicotinic acetylcholine receptor $\alpha$-subunits in the honeybee brain. Gene 2005, 344, 125-132. [CrossRef] [PubMed]

26. Jones, A.K.; Sattelle, D.B. Diversity of insect nicotinic acetylcholine receptor subunits. Adv. Exp. Med. Biol. 2010, 683, 25-43. [PubMed]

27. Gundelfinger, E.D.; Schulz, R. Insect nicotinic acetylcholine receptors: genes, structure, physiological and pharmacological properties. In Neuronal Nicotinic Receptors; Clementi, F., Fornasari, D., Gotti, C., Eds.; Springer-Verlag: Heidelberg, Germany, 2000; pp. 497-521.

28. Thany, S.H. Electrophysiological studies and pharmacological properties of insect native nicotinic acetylcholine receptors. Adv. Exp. Med. Biol. 2010, 683, 53-63.

29. Casida, J.E. Neonicotinoids and other insect nicotinic receptor competitive modulators: progress and prospects. Annu. Rev. Entomol. 2018, 63, 125-144. [CrossRef]

30. Tomizawa, M.; Casida, J.E. Selective toxicity of neonicotinoids attributable to specificity of insect and mammalian nicotinic receptors. Annu. Rev. Entomol. 2003, 48, 339-364. [CrossRef]

31. Cabirol, A.; Haase, A. The neurophysiological bases of the impact of neonicotinoid pesticides on the behaviour of honeybees. Insects 2019, 10, 344. [CrossRef]

32. Nauen, R.; Ebbinghaus-Kintscher, U.; Schmuck, R. Toxicity and nicotinic acetylcholine receptor interaction of imidacloprid and its metabolites in Apis mellifera (Hymenoptera: Apidae). Pest Manag. Sci. 2001, 57, 577-586. [CrossRef]

33. Déglise, P.; Grünewald, B.; Gauthier, M. The insecticide imidacloprid is a partial agonist of the nicotinic receptor of honeybee Kenyon cells. Neurosci. Lett. 2002, 321, 13-16. [CrossRef]

34. Palmer, M.J.; Moffat, C.; Saranzewa, N.; Harvey, J.; Wright, G.A.; Connolly, C.N. Cholinergic pesticides cause mushroom body neuronal inactivation in honeybees. Nat. Commun. 2013, 4, 1634. [CrossRef]

35. Grillone, G.; Laurino, D.; Manino, A.; Porporato, M. Toxicity of thiametoxam on in vitro reared honey bee brood. Apidologie 2017, 48, 635-643. [CrossRef]

36. Aupinel, P.; Fortini, D.; Michaud, B.; Marolleau, F.; Tasei, J.-N.; Odoux, J.-F. Toxicity of dimethoate and fenoxycarb to honey bee brood (Apis mellifera), using a newin vitro standardized feeding method. Pest Manag. Sci. 2007, 63, 1090-1094. [CrossRef] [PubMed]

37. Hendriksma, H.P.; Härtel, S.; Steffan-Dewenter, I. Honey bee risk assessment: new approaches for in vitro larvae rearing and data analyses. Methods Ecol. Evol. 2011, 2, 509-517. [CrossRef]

38. Tasei, J.-N.; Lerin, J.; Ripault, G. Sub-lethal effects of imidacloprid on bumblebees, Bombus terrestris (Hymenoptera: Apidae), during a laboratory feeding test. Pest Manag. Sci. 2000, 56, 784-788. [CrossRef]

39. De Souza Rosa, A.; Teixeira, J.S.G.; Vollet-Neto, A.; Queiroz, E.P.; Blochtein, B.; Pires, C.S.S.; Imperatriz-Fonseca, V.L. Consumption of the neonicotinoid thiamethoxam during the larval stage affects the survival and development of the stingless bee, Scaptotrigona aff. depilis. Apidologie 2016, 47, 729-738. [CrossRef]

40. Dai, P.; Jack, C.J.; Mortensen, A.N.; Bustamante, T.A.; Bloomquist, J.R.; Ellis, J.D. Chronic toxicity of clothianidin, imidacloprid, chlorpyrifos, and dimethoate to Apis mellifera L. larvae reared in vitro. Pest Manag. Sci. 2019, 75, 29-36. [CrossRef]

41. Rondeau, G.; Sánchez-Bayo, F.; Tennekes, H.A.; Decourtye, A.; Ramírez-Romero, R.; Desneux, N. Delayed and time-cumulative toxicity of imidacloprid in bees, ants and termites. Sci. Rep. 2015, 4, 5566. [CrossRef]

42. Sandrock, C.; Tanadini, L.G.; Pettis, J.S.; Biesmeijer, J.C.; Potts, S.G.; Neumann, P. Sublethal neonicotinoid insecticide exposure reduces solitary bee reproductive success. Agric. For. Entomol. 2014, 16, 119-128. [CrossRef] 
43. Woodcock, B.A.; Bullock, J.M.; Shore, R.F.; Heard, M.S.; Pereira, M.G.; Redhead, J.; Ridding, L.; Dean, H.; Sleep, D.; Henrys, P.; et al. Country-specific effects of neonicotinoid pesticides on honey bees and wild bees. Science 2017, 356, 1393-1395. [CrossRef]

44. Rundlöf, M.; Andersson, G.K.S.; Bommarco, R.; Fries, I.; Hederström, V.; Herbertsson, L.; Jonsson, O.; Klatt, B.K.; Pedersen, T.R.; Yourstone, J.; et al. Seed coating with a neonicotinoid insecticide negatively affects wild bees. Nature 2015, 521, 77-80. [CrossRef]

45. Rolke, D.; Fuchs, S.; Grünewald, B.; Gao, Z.; Blenau, W. Large-scale monitoring of effects of clothianidin-dressed oilseed rape seeds on pollinating insects in Northern Germany: effects on honey bees (Apis mellifera). Ecotoxicology 2016, 25, 1648-1665. [CrossRef] [PubMed]

46. Ellis, C.; Park, K.J.; Whitehorn, P.; David, A.; Goulson, D. The neonicotinoid insecticide thiacloprid impacts upon bumblebee colony development under field conditions. Environ. Sci. Technol. 2017, 51, 1727-1732. [CrossRef] [PubMed]

47. Siviter, H.; Brown, M.J.F.; Leadbeater, E. Sulfoxaflor exposure reduces bumblebee reproductive success. Nature 2018, 561, 109-112. [CrossRef] [PubMed]

48. Havstad, L.T.; Øverland, J.I.; Valand, S.; Aamlid, T.S. Repellency of insecticides and the effect of thiacloprid on bumble bee colony development in red clover (Trifolium pratense L.) seed crops. Acta Agric. Scand. Sect. B Soil Plant Sci. 2019, 69, 439-451. [CrossRef]

49. Henry, M.; Beguin, M.; Requier, F.; Rollin, O.; Odoux, J.-F.; Aupinel, P.; Aptel, J.; Tchamitchian, S.; Decourtye, A. A common pesticide decreases foraging success and survival in honey bees. Science 2012, 336, 348-350. [CrossRef] [PubMed]

50. Fischer, J.; Müller, T.; Spatz, A.-K.; Greggers, U.; Grünewald, B.; Menzel, R. Neonicotinoids interfere with specific components of naviagtion in honeybees. PLoS One 2014, 9, 1-10. [CrossRef]

51. Tison, L.; Hahn, M.-L.; Holtz, S.; Rößner, A.; Greggers, U.; Bischoff, G.; Menzel, R. Honey bees' behavior is impaired by chronic exposure to the neonicotinoid thiacloprid in the field. Environ. Sci. Technol. 2016, 50, 7218-7227. [CrossRef]

52. Alkassab, A.T.; Kirchner, W.H. Assessment of acute sublethal effects of clothianidin on motor function of honeybee workers using video-tracking analysis. Ecotoxicol. Environ. Saf. 2018, 147, 200-205. [CrossRef]

53. Decourtye, A.; Armengaud, C.; Renou, M.; Devillers, J.; Cluzeau, S.; Gauthier, M.; Pham-Delegue, M.H. Imidacloprid impairs memory and brain metabolism in the honeybee (Apis mellifera L.). Elsevier 2004, 78, 83-92. [CrossRef]

54. Tison, L.; Rößner, A.; Gerschewski, S.; Menzel, R. The neonicotinoid clothianidin impairs memory processing in honey bees. Ecotoxicol. Environ. Saf. 2019, 180, 139-145. [CrossRef]

55. Schneider, C.W.; Tautz, J.; Grünewald, B.; Fuchs, S. RFID tracking of sublethal effects of two neonicotinoid insecticides on the foraging behavior of Apis mellifera. PLoS One 2012, 7, e30023. [CrossRef] [PubMed]

56. Siefert, P.; Hota, R.; Ramesh, V.; Grünewald, B. Chronic within-hive video registrations detect altered nursing behaviour and retarded larval development of neonicotinoid treated honey bees. Sci. Rep.. under review.

57. Blacquiere, T.; Smagghe, G.; van Gestel, C.A.; Mommaerts, V. Neonicotinoids in bees: a review on concentrations, side-effects and risk assessment. Ecotoxicology 2012, 21, 973-992. [CrossRef] [PubMed]

58. Godfray, H.C.J.; Blacquière, T.; Field, L.M.; Hails, R.S.; Petrokofsky, G.; Potts, S.G.; Raine, N.E.; Vanbergen, A.J.; McLean, A.R. A restatement of the natural science evidence base concerning neonicotinoid insecticides and insect pollinators. Proc. R. Soc. B Biol. Sci. 2014, 281, 20140558. [CrossRef] [PubMed]

59. Godfray, H.C.J.; Blacquière, T.; Field, L.M.; Hails, R.S.; Potts, S.G.; Raine, N.E.; Vanbergen, A.J.; McLean, A.R. A restatement of recent advances in the natural science evidence base concerning neonicotinoid insecticides and insect pollinators. Proc. R. Soc. B Biol. Sci. 2015, 282, 20151821. [CrossRef]

60. Wood, T.J.; Goulson, D. The environmental risks of neonicotinoid pesticides: a review of the evidence post 2013. Environ. Sci. Pollut. Res. 2017, 24, 17285-17325. [CrossRef]

61. Jones, A.K.; Raymond-Delpech, V.; Thany, S.H.; Gauthier, M.; Sattelle, D.B. The nicotinic acetylcholine receptor gene family of the honey bee, Apis mellifera. Genome Res. 2006, 16, 1422-1430. [CrossRef]

62. Barbara, G.S.; Grünewald, B.; Paute, S.; Gauthier, M.; Raymond-Delpech, V. Study of nicotinic acetylcholine receptors on cultured antennal lobe neurones from adult honeybee brains. Invertebr. Neurosci. 2008, 8, 19-29. [CrossRef]

63. Himmelreich, S.; Grünewald, B. Cellular physiology of olfactory learning in the honeybee brain. Apidologie 2012, 43, 308-321. [CrossRef] 
64. Bicker, G.; Kreissl, S. Calcium imaging reveals nicotinic acetylcholine receptors on cultured mushroom body neurons. J. Neurophysiol. 1994, 71, 808-810. [CrossRef]

65. Lapied, B.; Le Corronc, H.; Hue, B. Sensitive nicotinic and mixed nicotinic-muscarinic receptors in insect neurosecretory cells. Brain Res. 1990, 533, 132-136. [CrossRef]

66. Tomizawa, M.; Casida, J.E. Neonicotinoid insecticide toxicology: mechanisms of selective action. Annu. Rev. Pharmacol. Toxicol. 2005, 45, 247-268. [CrossRef] [PubMed]

67. Jeschke, P.; Nauen, R. Neonicotinoids-from zero to hero in insecticide chemistry. Pest Manag. Sci. 2008, 64, 1084-1098. [CrossRef] [PubMed]

68. Jeschke, P.; Nauen, R.; Beck, M.E. Nicotinic acetylcholine receptor agonists: a milestone for modern crop protection. Angew. Chemie Int. Ed. 2013, 52, 9464-9485. [CrossRef] [PubMed]

69. Lozano, V.C.; Bonnard, E.; Gauthier, M.; Richard, D. Mecamylamine-induced impairment of acquisition and retrieval of olfactory conditioning in the honeybee. Behav. Brain Res. 1996, 81, 215-222. [CrossRef]

70. Gauthier, M.; Dacher, M.; Thany, S.H.; Niggebrügge, C.; Déglise, P.; Kljucevic, P.; Armengaud, C.; Grünewald, B. Involvement of alpha-bungarotoxin-sensitive nicotinic receptors in long-term memory formation in the honeybee (Apis mellifera). Neurobiol. Learn. Mem. 2006, 86, 164-174. [CrossRef] [PubMed]

71. Andrione, M.; Vallortigara, G.; Antolini, R.; Haase, A. Neonicotinoid-induced impairment of odour coding in the honeybee. Sci. Rep. 2016, 6, 38110. [CrossRef] [PubMed]

72. Collin, C.; Hauser, F.; de Valdivia, E.G.; Li, S.; Reisenberger, J.; Carlsen, E.M.M.; Khan, Z.; Hansen, N.Ø.; Puhm, F.; Søndergaard, L.; et al. Two types of muscarinic acetylcholine receptors in Drosophila and other arthropods. Cell. Mol. Life Sci. 2013, 70, 3231-3242. [CrossRef]

73. Xia, R.-Y.; Li, M.-Q.; Wu, Y.-S.; Qi, Y.-X.; Ye, G.-Y.; Huang, J. A new family of insect muscarinic acetylcholine receptors. Insect Mol. Biol. 2016, 25, 362-369. [CrossRef]

74. Henschler, D. Hoher Acetylcholingehalt von Bienenfuttersäften. Naturwissenschaften 1954, 41, 142. [CrossRef]

75. Goldschmidt, S.; Burkert, H. Die Hydrolyse des cholinergischen Honigwirkstoffes und anderer Cholinester mittels Cholinesterasen und deren Hemmung im Honig. Hoppe Seyler's Zeitschrift für Physiol. Chemie 1955, 301, 78-89. [CrossRef]

76. Wessler, I.; Gärtner, H.-A.; Michel-Schmidt, R.; Brochhausen, C.; Schmitz, L.; Anspach, L.; Grünewald, B.; Kirkpatrick, C.J. Honeybees produce millimolar concentrations of non-neuronal acetylcholine for breeding: possible adverse effects of neonicotinoids. PLoS One 2016, 11, e0156886. [CrossRef] [PubMed]

77. Welsh, J.H.; Nogueira-Neto, P.; Jaeger, C.P.; Ancona Lopez, A.A. Acetylcholine in the larval food, honey and stored pollen of a stingless bee, Melipona quadrifasciata. Bol. da Fac. Filos. Ciências e Let. Univ. São Paulo. Zool. 1965, 25, 105. [CrossRef]

78. Valente, D.; Marques, L.A.C.; Mendes, E.G. The acetylcholine contents of honeys from different bees as determined in four-point-assays. Comp. Biochem. Physiol. Part C Comp. Pharmacol. 1981, 69, 161-164. [CrossRef]

79. Shuel, R.W.; Dixon, S.E. Studies in the mode of action of royal jelly in honeybee development: II. Respiration of newly emerged larvae on various substrates. Can. J. Zool. 1959, 37, 803-813. [CrossRef]

80. Jung-Hoffmann, I. Die Determination von Königin und Arbeiterin der Honigbiene. Z. Bienenforsch. 1966, 8, 296-322.

81. Henschler, D.; von Rhein, W. Änderungen des Acetylcholingehaltes von Bienenfuttersäften in der Madenentwicklung. Naturwissenschaften 1960, 47, 326-327. [CrossRef]

82. Colhoun, E.H.; Smith, M.V. Neurohormonal properties of royal jelly. Nature 1960, 188, 854-855. [CrossRef]

83. Yang, E.-C.; Chang, H.-C.; Wu, W.-Y.; Chen, Y.-W. Impaired olfactory associative behavior of honeybee workers due to contamination of imidacloprid in the larval stage. PLoS One 2012, 7, e49472. [CrossRef]

84. Tan, K.; Chen, W.; Dong, S.; Liu, X.; Wang, Y.; Nieh, J.C. A neonicotinoid impairs olfactory learning in Asian honey bees (Apis cerana) exposed as larvae or as adults. Sci. Rep. 2015, 5, 1-8. [CrossRef]

85. Decourtye, A.; Devillers, J. Ecotoxicity of neonicotinoid insecticides to bees. Adv. Exp. Med. Biol. 2010, 683, 85-95. [PubMed]

86. Wu, J.Y.; Anelli, C.M.; Sheppard, W.S. Sub-lethal effects of pesticide residues in brood comb on worker honey bee (Apis mellifera) development and longevity. PLoS One 2011, 6, e14720. [CrossRef] [PubMed]

87. Abbott, V.A.; Nadeau, J.L.; Higo, H.A.; Winston, M.L. Lethal and sublethal effects of imidacloprid on Osmia lignaria and clothianidin on Megachile rotundata (Hymenoptera: Megachilidae). J. Econ. Entomol. 2008, 101, 784-796. [CrossRef] 
88. Böhme, F.; Bischoff, G.; Zebitz, C.P.W.; Rosenkranz, P.; Wallner, K. From field to food-Will pesticide-contaminated pollen diet lead to a contamination of royal jelly? Apidologie 2018, 49, 112-119.

89. Wittmann, D. Tracer experiments on the passage of insecticides through nurse bees as a basis for determining intoxication routes in honeybee larvae. Apidologie 1982, 13, 328-330.

90. Davis, A.R.; Shuel, R.W. Distribution of 14 C-labelled carbofuran and dimethoate in royal jelly, queen larvae and nurse honeybees. Apidologie 1988, 19, 37-50. [CrossRef]

91. Rockstein, M. The relation of cholinesterase activity to change in cell number with age in the brain of the adult worker honeybee. J. Cell. Comp. Physiol. 1950, 35, 11-23. [CrossRef]

92. Ament, S.A.; Wang, Y.; Robinson, G.E. Nutritional regulation of division of labor in honey bees: toward a systems biology perspective. Wiley Interdiscip. Rev. Syst. Biol. Med. 2010, 2, 566-576. [CrossRef]

93. Deseyn, J.; Billen, J. Age-dependent morphology and ultrastructure of the hypopharyngeal gland of Apis mellifera workers (Hymenoptera, Apidae). Apidologie 2005, 36, 49-57. [CrossRef]

94. Crailsheim, K. Interadult feeding of jelly in honeybee (Apis mellifera L.) colonies. J. Comp. Physiol. B 1991, 161, 55-60. [CrossRef]

95. Crailsheim, K. The flow of jelly within a honeybee colony. J. Comp. Physiol. B 1992, 162, 681-689. [CrossRef]

96. Hatjina, F.; Papaefthimiou, C.; Charistos, L.; Dogaroglu, T.; Bouga, M.; Emmanouil, C.; Arnold, G. Sublethal doses of imidacloprid decreased size of hypopharyngeal glands and respiratory rhythm of honeybees in vivo. Apidologie 2013, 44, 467-480. [CrossRef]

97. Heylen, K.; Gobin, B.; Arckens, L.; Huybrechts, R.; Billen, J. The effects of four crop protection products on the morphology and ultrastructure of the hypopharyngeal gland of the European honeybee, Apis mellifera. Apidologie 2011, 42, 103-116. [CrossRef]

98. Škerl, M.I.S.; Gregorc, A. Heat shock proteins and cell death in situ localisation in hypopharyngeal glands of honeybee (Apis mellifera carnica) workers after imidacloprid or coumaphos treatment. Apidologie 2010, 41, 73-86. [CrossRef]

99. De Smet, L.; Hatjina, F.; Ioannidis, P.; Hamamtzoglou, A.; Schoonvaere, K.; Francis, F.; Meeus, I.; Smagghe, G.; de Graaf, D.C. Stress indicator gene expression profiles, colony dynamics and tissue development of honey bees exposed to sub-lethal doses of imidacloprid in laboratory and field experiments. PLoS One 2017, 12, e0171529. [CrossRef]

100. Menail, H.A.; Bouchema-Boutefnouchet, W.F.; Smagghe, G.; Ayad-Loucif, W. Thiamethoxam (neonicotinoid) and spinosad (bioinsecticide) affect hypopharyngeal glands and survival of Apis mellifera intermissa (Hymenoptera: Apidae). In Proceedings of the Recent Advances in Environmental Science from the Euro-Mediterranean and Surrounding Regions. EMCEI 2017. Advances in Science, Technology \& Innovation (IEREK Interdisciplinary Series for Sustainable Development); Kallel, A., Ksibi, M., Ben Dhia, H., Khélifi, N., Eds.; Springer: Cham, Switzerland, 2018; pp. 347-349.

101. Renzi, M.T.; Rodríguez-Gasol, N.; Medrzycki, P.; Porrini, C.; Martini, A.; Burgio, G.; Maini, S.; Sgolastra, F. Combined effect of pollen quality and thiamethoxam on hypopharyngeal gland development and protein content in Apis mellifera. Apidologie 2016, 47, 779-788. [CrossRef]

102. Berenbaum, M.R.; Liao, L.-H. Honey bees and environmental stress: Toxicologic pathology of a superorganism. Toxicol. Pathol. 2019, 019262331987715. [CrossRef]

103. Christen, V.; Kunz, P.Y.; Fent, K. Endocrine disruption and chronic effects of plant protection products in bees: Can we better protect our pollinators? Environ. Pollut. 2018, 243, 1588-1601. [CrossRef]

104. Baines, D.; Wilton, E.; Pawluk, A.; De Gorter, M.; Chomistek, N. Neonicotinoids act like endocrine disrupting chemicals in newly-emerged bees and winter bees. Sci. Rep. 2017, 7, 1-18. [CrossRef]

105. Cook, S.C. Compound and dose-dependent effects of two neonicotinoid pesticides on honey bee (Apis mellifera) metabolic physiology. Insects 2019, 10, 11-14. [CrossRef]

106. Snodgrass, R.E. Anatomy of the Honey Bee; Cornell University Press: London, UK, 1956.

107. Yu, Y.-S.; Xue, S.; Wu, J.-C.; Wang, F.; Yang, G.-Q. Changes in levels of juvenile hormone and molting hormone in larvae and adult females of Chilo suppressalis (Lepidoptera: Pyralidae) after imidacloprid applications to rice. J. Econ. Entomol. 2007, 100, 1188-1193. [CrossRef]

108. Kou, R. Cholinergic regulation of the corpora allata in adult male loreyi leafworm Mythimna loreyi. Arch. Insect Biochem. Physiol. 2002, 49, 215-224. [CrossRef] [PubMed]

109. Christen, V.; Mittner, F.; Fent, K. Molecular effects of neonicotinoids in honey bees (Apis mellifera). Environ. Sci. Technol. 2016, 50, 4071-4081. [CrossRef] [PubMed] 
110. Derecka, K.; Blythe, M.J.; Malla, S.; Genereux, D.P.; Guffanti, A.; Pavan, P.; Moles, A.; Snart, C.; Ryder, T.; Ortori, C.A.; et al. Transient exposure to low levels of insecticide affects metabolic networks of honeybee larvae. PLoS One 2013, 8, e68191. [CrossRef]

111. Gregorc, A.; Evans, J.D.; Scharf, M.; Ellis, J.D. Gene expression in honey bee (Apis mellifera) larvae exposed to pesticides and Varroa mites (Varroa destructor). J. Insect Physiol. 2012, 58, 1042-1049. [CrossRef]

112. Schmehl, D.R.; Teal, P.E.A.; Frazier, J.L.; Grozinger, C.M. Genomic analysis of the interaction between pesticide exposure and nutrition in honey bees (Apis mellifera). J. Insect Physiol. 2014, 71, 177-190. [CrossRef]

113. Claudianos, C.; Ranson, H.; Johnson, R.M.; Biswas, S.; Schuler, M.A.; Berenbaum, M.R.; Feyereisen, R.; Oakeshott, J.G. A deficit of detoxification enzymes: pesticide sensitivity and environmental response in the honeybee. Insect Mol. Biol. 2006, 15, 615-636. [CrossRef]

114. Mogren, C.L.; Lundgren, J.G. Neonicotinoid-contaminated pollinator strips adjacent to cropland reduce honey bee nutritional status. Sci. Rep. 2016, 6, 29608. [CrossRef]

115. Wilde, J.; Frączek, R.J.; Siuda, M.; Bąk, B.; Hatjina, F.; Miszczak, A. The influence of sublethal doses of imidacloprid on protein content and proteolytic activity in honey bees (Apis mellifera L.). J. Apic. Res. 2016, 55, 212-220. [CrossRef]

116. Rand, E.E.; Smit, S.; Beukes, M.; Apostolides, Z.; Pirk, C.W.W.; Nicolson, S.W. Detoxification mechanisms of honey bees (Apis mellifera) resulting in tolerance of dietary nicotine. Sci. Rep. 2015, 5, 11779. [CrossRef]

117. Du Rand, E.E.; Human, H.; Smit, S.; Beukes, M.; Apostolides, Z.; Nicolson, S.W.; Pirk, C.W.W. Proteomic and metabolomic analysis reveals rapid and extensive nicotine detoxification ability in honey bee larvae. Insect Biochem. Mol. Biol. 2017, 82, 41-51. [CrossRef] [PubMed]

(C) 2019 by the authors. Licensee MDPI, Basel, Switzerland. This article is an open access article distributed under the terms and conditions of the Creative Commons Attribution (CC BY) license (http://creativecommons.org/licenses/by/4.0/). 